\title{
Understanding music's therapeutic efficacy: Implications for music education
}

\author{
D THRAM
}

\begin{abstract}
In the current era of electronic domination of human experience, be it via cell phone and/or computer addiction, or the ubiquitous television, actual participation in musicmaking is less and less common for the average person, child or adult. Passive participation through listening is most often cited by people as their major experience with music in their lives. When asked if listening has therapeutic effects, it is rare for anyone to respond in the negative. Likewise, for performers/active participants in musicmaking, be it solitary or as part of a group, invariably an enhanced sense of well-being from the act of making music is reported.

This paper addresses therapeutic aspects of musical participation (singing, clapping, playing an instrument, dancing, listening) by providing a historical overview $\left(12^{\text {th }} \mathrm{c}\right.$ to present) of attitudes toward music's therapeutic effects. It argues that music exists through the interaction of our biological capacity to make music with our cultural circumstances. How individuals benefit in all aspects their being - physical, mental and emotional - from engaging in the act of making music is illustrated with examples from field research in southern Africa. Finally implications for Music Education are explored which emphasize how more comprehensive integration of music into the curriculum can serve as an antidote to the increasing isolation and alienation of modern life.
\end{abstract}

Keywords. Musical participation, well-being, biological and cultural interaction, music education

\section{Introduction}

In this paper ${ }^{2}$ I suggest that music's efficacy for teaching and learning lies not only in the pedagogy of how to create music (e.g. how to play a given instrument, how to compose, how to read notation, etc.), or in the many tangential benefits that are inherent in making music (e.g. promotion of mental concentration, non-verbal communication, creative expression,

Diane Thram is Associate Professor and Director of the International Library of African Music (ILAM), a heritage archive and research institute at Rhodes University. She has published numerous articles and book chapters from her research on the therapeutic dimension of music making in indigenous religion in Southern Africa. She edits ILAM's accredited academic journal, African Music and directs ILAM research and repatriation initiatives. (d.thram@ru.ac.za)

A more extensive version of this paper was published as a chapter of the same title in Bowman, W. and Frega, A.L. (eds.). The Oxford Handbook of Philosophy in Music Education. New York: Oxford University Press. p.192-209 (2012).. 
ability to memorize, etc.), or in learning to listen to music in depth, or in learning about the music of the various cultures of the world. I suggest that music's efficacy for teaching and learning also lies in the ways in which music is therapeutic.

In the current era of globally mediated electronic domination of human experience in general, and experience of music in particular, be it via cell phone with music downloads, MP3 player, computer internet addiction, CDs/DVDs, or MTV, actual group participation in musicmaking is less and less common for the average person, child or adult. Participation by listening is cited by the majority of students in my world music classes as their major experience with music in their lives. When asked if listening has therapeutic effects, it is rare for anyone to respond in the negative. Likewise and importantly, musicians/performers, be it by singing, dancing or playing an instrument, invariably report an enhanced sense of wellbeing as a result of their participation in music making. Publications from field research by various ethnomusicologists and anthropologists ${ }^{3}$ speak to the unique, positive, therapeutic power of group participation in making music evidenced in indigenous cultures in which group participation carries as great or greater value than individual expertise or virtuosic musicianship. In these cultures music making is part of an everyday life in which music's therapeutic potential is routinely activated through group participation.

Questioning of the Western ideal of individual excellence in performance of music, engendered by the model of prize-awarding competitions and comprehensive standards for achievement found in music curriculums in most educational institutions, is gaining currency. This may be due to increased awareness that the Western model excludes too many students from participation in music making and thereby from the benefit of its positive side-effects. My philosophy of music education advocates equal opportunity for group participation in music making be provided as part of the music curriculum, and further that teachers and policy makers ensure that no students be excluded from group music making activities because they are not performing at a prescribed level of competence. This is not to negate competence based activities such as school orchestras, bands and choirs, but it is to advocate the provision of group music making activities for all students because of the way they promote social bonding, break down alienation, provide a creative outlet for students, and provide opportunities for formation of positive group identity.

In the brief overview that follows, music's therapeutic effects are examined in light of historical research/historiography on attitudes toward music and its therapeutic powers from the $12^{\text {th }}-18^{\text {th }}$ centuries, as exemplified in the work of two remarkable early European musician/composer/philosophers, Hildegard von Bingen (1098-1179) and Marcilio Ficino (1433-1499). Following Penelope Gouk's finding (2004: 104) of a historical shift in attitude toward music's therapeutic power during the $15^{\text {th }}$ to $18^{\text {th }}$ centuries, from the medieval, premodern, magical world view's 'nature is musical', to the early modern (with the advent of Newtonian physics), rational world view's 'music is natural', I add consideration of the shift to the modern/post-modern 'music is cultural' paradigm. Evidence from my field research of how group participation in music making serves to enhance music's power in ritual events and also serves to heal social ills and promote social cohesion is introduced as illustrative of the 'ethic of group participation' (cf Turino 2000, 2008) found in many indigenous cultures.

For contextualized studies of music's therapeutic dimension, music and healing, and benefits of group participation in music making see Barz, 2006; Berliner, 1978; Feld and Keil 1994; Friedson 1996; Koen, ed. 2008; Roseman 1991; Thram 1999; Turino 1993, 2000, 2008; and anthropologists Biesele 1993; Janzen, 1992; Kapferer, 1986 to mention a few. 


\section{Music's therapeutic efficacy}

Without foregrounding the long-standing nature-nurture debate over music's origin, I argue that music's therapeutic efficacy is found in its power to effect change in how human beings feel and that this power is located - regardless of particular cultural context or particular historical era - in the biological foundation of music's therapeutic efficacy in human sensory and neurological capabilities. For this reason, I recommend that music educators embrace music's therapeutic dimension. I contend that the power of musical participation to positively transform how people feel is one of the most salient reasons for music making to be part of every student's school experience.

I have chosen to address the nature is musical worldview through two major historical figures whose work left a wealth of insight into the earliest recorded attitudes of the medieval and early modern eras. Beginning with the medieval Benedictine abbess, author, composer, and visionary, Hildegard of Bingen (1098-1179), then moving to the Florentine priest, theologian, astrologer, physician, musician and writer, Marsilio Ficino (1433-1499), whose revival of Platonic thought made him one of the most influential scholars of the Renaissance (Voss 2001: 154), and ending with reference to contemporary writing on music's place in human evolution and the role of group participation in the emergence of culture, I will elucidate some highlights of the historical trajectory of attitudes toward music's therapeutic efficacy and suggest their potential significance for music education in the $21^{\text {st }}$ century.

\section{Hildegard of Bingen}

Hildegard of Bingen's holistic world view is evident in her attitude toward music and its place in the cosmos and provides empirical evidence of the 'nature is musical' paradigm. In conformity with the early medieval music theory of Boethius's De Musica and its concept of "cosmic harmony" (musica mundana), Hildegard believed each element (fire, water, air, earth) retained a distinctive "pristine sound that it had at the time of creation" (Schipperges 1997: 27). She thought that mankind and the cosmos were joined in a unique musical harmony which is able to bring everyone's "hearts into consonance" as well as provide guidance for a healthy life and a foundation for "an effective system of healing and therapy" (19).

To this end, she composed a cycle of over seventy songs (preserved using neume notation) that she named Symphony of the Harmony of Celestial Revelations. Hildegard's antiphons, sequences, responsories, and hymns are regarded by musicologists as a "self-contained work of art which might long ago have given rise to a theology of music" (20). Her accounts of her visions on the relationship between God and humanity, the cosmos, and music's place within it in her literary works, her sermons, and records of her meetings and copious correspondence with the religious and political leaders of her time, including Pope Alexander III and Emperor Frederick I, were preserved by her scribe, the monk Volmar (20-22) and provide an authoritative source on social and political life in $12^{\text {th }}$ century Europe.

Her treatises on natural history and the healing arts entitled Causes and Cures, and Physica, written between 1150 and $1160 \mathrm{CE}$, display her deep understanding and empathy with the interconnectedness of all things in nature and her penetrating insight into realities of daily life including health and disease (63). She saw music as "a kind of regulator, a therapeutic agent of the first order", and as "an especially important factor in directing a person's inner life." Her belief was that, in earthly existence, oneness with the primal harmonies, the "harmony of 
the spheres', had been broken, but every song served to remind its singers of the nature of the celestial harmonies and that - through their human capacity to make music - they were once in harmony with all of creation (86). For Hildegard, harmony was achieved through music, and music like all art was divinely inspired. The nuns in her abbey were described, in contemporary reports of their performances, as standing in the choir with their hair flowing over their shoulders wearing white silk veils and golden wreathes or crowns and rings on their fingers - singing Hildegard's symphony of songs, with up-lifting lyrics and instrumental accompaniment on the finest instruments (20-1).

That Hildegard was charismatic, powerful, and highly respected in a time when the realms of religion and politics were dominated by men is well documented. She made her contribution as a composer and performer of music tangible for posterity through descriptions of her techniques according to her "laws of numbers and sound, melody and rhythm" (27). Her advocacy of the use of music as a 'therapeutic agent' to create harmony in one's personal life remains cogent ten centuries after her death, and points to the timelessness of the core realities of human experience.

\section{Marcilio Ficino}

By the $15^{\text {th }}$ century the prevailing worldview - although considered to be highly articulated and rational - remained magical in that scholars were preoccupied with trying to understand the universe in terms of unseen forces whose effects on people music had the power to regulate (Horden 2000: 148-49). Marsilio Ficino (1433-1499), architect of the scientific practice of 'natural magic', tried to discover and recover the powers of music described by the philosophers of antiquity. He spawned the revival of Platonic philosophy by translating and editing ancient texts in his search for the secrets to music's therapeutic potential. Intellectually his goal was to integrate Platonism and Christianity, and in practice "his holistic approach to healing revealed a new way of understanding and participating in the world ...based on his reading of Hermetic, neo-Platonic and Arabic texts combined with his medical, astrological and musical skills" (Voss 2000: 154). Viewing the human soul as the force that joined mind and body, he sought to bring it into harmony with the 'soul of the world', the force that joined heaven and earth. From his experience as a musician who accompanied himself on lyre as he sang the hymns of Orpheus (which he knew intimately having translated them from Greek into Latin), Ficino was convinced that the most powerful way to accomplish this unity or balance in life was through "the careful preparation and performance of music" (ibid.).

During the early modern era following the Reformation, which lasted more than a century after its instigation by Luther in 1517, Protestants and Catholics alike were searching for the proper way for humans to approach the divine, and the role of music in worship and in life in general was an issue of great importance. It was generally known and believed that in ancient civilization music had great power over human morals and behavior. What was the source of this power? How could it be restored? Ficino's publications held great appeal because they dealt directly with this subject matter and tried to answer just those questions. In addition, they were considered scientific because they were informed by the ideas of proportion in nature espoused by Pythagoras, the mathematical principles of vibration explained in Ptolemy's Harmonics (in the $2^{\text {nd }}$ century A.D.), and Plotinus's Enneads (written in the $3^{\text {rd }}$ 
century A.D.), a neo-platonic text not known in the Middle Ages that he edited in 1492 (Gouk 2004: 93-4, 100-02).

Ficino's influence was at its height in the late sixteenth century when his Di Vita Libri Tres (Three Books on Life), an authoritative health manual he had published a century earlier in 1489, was consulted widely because it contained "practical techniques for creating songs that will draw down beneficial planetary emanations", thus giving specific ways for musical sound to serve as the mediator to create harmony between mankind and the divine - between earthly and heavenly domains (Gouk 2004: 93, 101). Di Vita provided the basis for the ways Europeans with the benefit of education viewed music's effects on the mind, body, and soul well into the seventeenth century (Schiesari 1992 in Gouk 2004: 93). In 1462, not quite four decades after the invention of the printing press, and twenty seven years before he published his Three Books on Life, Ficino published his translations of various ancient writings thought to be authored by Hermes and Plato, plus his edition of the Hymns of Orpheus (Walker 1972 in Gouk 2004: 100-01). Ficino's aim was to re-capture the healing effects these magi were thought to have achieved through singing and incantation, such as curing of diseases of the soul and body, removing evil desires, and bringing the soul "into a state of virtuous harmony" (Gouk 2004: 100).

Like Hildegard, Ficino sought, through music, to return humans to their original, pristine condition, when they were in harmony with the whole of creation. He found what he believed to be the source of music's power in Plato's Timaeus, where a creation myth is recorded that demonstrates "the musical principle of proportionality underlying the whole cosmos." In the myth Cosmic Mind and Matter are divided into the ratios of 2:1, 3:2, and 4:3. These ratios "produce the perfect intervals of octave, fourth and fifth, which were understood to represent in sound the very structure and fabric of creation" (Voss 2000: 157). One wonders if Hildegard's "laws of numbers and sound, melody and rhythm" mentioned earlier were based on knowledge of these ratios. Clearly, for both her and Ficino, music held the key to bringing one's self into harmony with the universe; and this balance, realized in the inherent structure of pitched sound that every human has the capacity to create, was positive proof that 'nature is musical'.

In what follows I attempt to show why Ficino's understanding of how music works in our bodies to produce positive effects is important as a precursor to the shift from the 'nature is musical' to the 'music is natural' paradigm, and why it is relevant to a question that begs an answer; the question, what is it that gives music its therapeutic power? Ficino lived in a time prior to understanding of the physiology of the human nervous system, a time when the human body was believed to be a microcosm of the forces of the cosmos, a time in which the neo-Platonists argued that "the heavenly bodies exert their influence on the earth (and vice versa) according to two principles, both of which are connected to the physical and mathematical properties of music" (Gouk 2004: 102).

The first principle, the pneuma is the world soul, "an extremely fine medium that permeates the cosmos, intermingles with earthly matter, and can bring about changes in its form" due to the tonos (tension) that gives it its dynamic quality. The way the world soul moves through earthly matter was thought to be through sympathetic vibration, just as the remaining strings of the lyre vibrate sympathetically with the string that is plucked, if tuned to the same pitch. The second principle, also deriving from the concept of vibration (as explained in Ptolemy's Harmonics) contends that "the same harmonic proportions govern planetary relationships 
(musica mundana), the relationship between body, spirit, and soul (musica bumana), and musical sound (musica instrumentalis)" (ibid.)

Ficino viewed music as animated, as having a life of its own. In his commentary on Plato's Timaeus he says, "Musical sound, more than anything else perceived by the senses, conveys, as if animated, the emotions and thoughts of the singer's or player's soul to the listener's souls" (Ficino, Opera, vol. 1, p. 1417 in Voss 2000: 164). Furthermore, integrating astrology into his prescriptions for what music was most suitable for any given person, he asserted "attention must be paid to the particular energies to which he is susceptible - that is to his dominant planets at birth whose qualities the soul indelibly imprints on his spiritus, the medium through which musical sound can reach 'the inmost recesses of the mind"' (Voss 2000: 165).

Gouk interprets Ficino's concept of the human spiritus thus: "The spiritus, in other words is a corporeal vapor that acts as the link between the body and the incorporeal soul and serves as the instrument for sense perception, imagination, and motor activity" (2004: 102 emph. mine). From the foregoing, it is clear that Ficino understood music's therapeutic efficacy to be located in the body's capability to hear (sense perception) and its ability to transmit what it hears to affect all potentials of human experience - physical (motor activity), mental (imagination) and emotional (incorporeal soul). Thus, Ficino, writing in the $15^{\text {th }}$ century, understood the biological foundation of music's therapeutic efficacy in human sensory and neurological capabilities.

From published accounts of Ficino's understanding of how music moves through the body, it appears that his concept of human spiritus corresponds to what we now know as the human nervous system, since he realized transmission of sound required reception through the ear, where the auditory nerve carries sound directly to the brain and throughout the body. However, because the physiology of the ear and the nervous system were not known or understood until several centuries later, his concepts and terminology seem strange to twentyfirst century readers and require interpretation by historians familiar with the pre-modern era.

Ficino's prescriptions of certain types of music for certain complaints, most notably melancholia, were highly regarded by educated Europeans for three centuries beyond their publication. His work was also a precursor of the medical model in which prescriptions are given by an individual practitioner to the individual patient for specific complaints. Gouk contends, “... Marsilio Fucino was the first ... Western medical theorist who actually went beyond literary platitudes in his attempt to recreate an ancient spiritual medicine ... The music-spirit theory expounded in his Three Books on Life was taken up enthusiastically by court poets and composers in the later $16^{\text {th }}$ century, but seems to have been ignored by most academic physicians of the time." It wasn't until the mid $-18^{\text {th }}$ century that medical works devoted to the effects of music and its potential benefits for mental health began to be published (Gouk 2000a: 9).

\section{Music is natural}

It was the Scientific Revolution of the 'Enlightenment' (17-18 ${ }^{\text {th }}$ centuries) that brought with it understanding of the human body according to the mechanistic model, which no longer allowed for invisible, intangible forces that could not be proven by accepted scientific methods. The existence of the soul, if allowed at all, was relegated to the realm of religion and no longer considered part of the human biological construct since its existence could not be scientifically proven. Thus the paradigm shift from the magical world view's 'nature is 
musical' to the rational world view that 'music is natural' i.e. a capacity available to all humans because of their biological make-up, took place during the early modern era for those with the benefit of formal education and the ability to read what was being published at the time.

Another shift that deserves mention began in the $18^{\text {th }}$ century with industrialization and urbanization and has continued through the $19^{\text {th }}$ and $20^{\text {th }}$ centuries up to the present. With the change from largely agrarian to largely urban, cosmopolitan, secularized life styles came the emergence of the elite model of rehearsed, staged performance with virtuosic performers viewed by spectators and a decrease in music events such as seasonal rituals and festivals in which everyone participated by singing and dancing. ${ }^{4}$ Audience participation in staged events was confined to attentive listening, applause, and shouting either approval or disapproval of the performance. The point here is that - with the emergence of staged performance with spectators - everyone no longer danced the dance. The practice of ritual events in which everyone participated evolved into staged performances by trained experts with an audience of observers who merely watched and listened. Music events with participants separated by the stage into performers and spectators became the norm during the early-modern era which also saw the emergence of another paradigm in regard to how music is understood, at least partially brought about by the emergence of two disciplines: ethnomusicology and anthropology.

\section{Music is cultural}

The practice of extended field research in non-western cultures and subsequent analysis of data gathered by researchers living in the cultural context being studied led to the understanding that music's meaning is not universal, but rather is relative to the culture that gave rise to it. The 'music is culture' / 'music as culture' paradigm articulated by Alan Merriam in The Anthropology of Music (1964) became what might be considered the mantra of ethnomusicology. With it also came the realization that culture is not static, but rather constantly shaped and re-shaped through the interaction of tradition and creativity (cf Biesele, 1993).

With increased evidence that the expressive forms that constitute culture are highly elaborated throughout all cultures of the world came the realization that culture cannot be viewed on a continuum of simple to complex, as the evolutionary paradigm of the $19^{\text {th }}$ century believed. By the mid $-20^{\text {th }}$ century scholars of culture put aside evolutionary thought as a framework for analysis of culture. The 'music is natural' (music is biological) paradigm, though over-shadowed by studies stressing musical meaning in specific cultural contexts, was not left behind. It was possibly more firmly established because of the influential work of ethnomusicologist, John Blacking, and his seminal How Musical is Man?(1973) and numerous other articles in which he argues for the biological basis of our ability to make music (cf Byron, ed. 1995). The co-existence of the two paradigms, 'music is natural' and 'music is cultural' is very succinctly stated by Ian Cross (2001: 40) when he says, "...while music may be in our biologies, our culture is in our music."

4 cf Thram, 1999: 236-45 for an analysis of the transition from ritual to art and the emergence of staged performance with an audience of spectators. The analysis of the transition from ritual to art is not intended to discount or disregard the formal concert or staged music events in general as a bona fide way to experience music and feel better as a result. 
Thus what emerged was co-existence of the 'music is natural' and 'music is cultural' paradigms. Debate over how to understand music continues, with considerable attention given to the source/origin of our capacity to make music. Cross $(2001,2003)$ reviews current thought on music's place in human evolution and observes that earlier evolutionary thought which believed that human behavior is determined by our genetic make-up has been replaced with the a more inclusive view which "interprets mature adult behaviors as shaped by both biology and culture" (2003: 24). Pertinent to our discussion of co-existence of the "music is natural' and 'music is cultural' paradigms is his assertion, "..given that our cultural lives are mainly evidenced in material behaviors and their traces, a clean dissociation between culture and biology - or between music and evolution - is unfeasible" (20). He goes on to argue that, although the cultures of the world produce many diverse forms of music, they cannot be reduced or knowable solely in terms of evolution, and certainly not in terms of adult musical behavior that is judged in evolutionary terms, since adult musical behavior is clearly conditioned by the culture one is born into and whatever other cultures one has contact with during the years of maturing (21).

However, he demonstrates that the relationship between the various music(s) of the world and evolution is possible to understand and define if one looks to evidence from studies of infant behavior which indicate that infants possess proto-musical capabilities cross-culturally (25-27). He contends, "If evolution has shaped the human mind, it has most likely selected at the level of infant predispositions, and culture can be thought of as shaping into specific and distinct forms the expression of those predispositions" (25). The interaction of our biological capabilities with our cultural circumstances is inevitable and cannot be separated. Music cannot be reduced to either one or the other, it is produced via interaction of both. Furthermore, proto-musical capabilities in infants and children by their very nature lend themselves to social interaction that is cooperative and non-threatening, and since each child is able to have his/her own 'take' on the musical communication occurring - there is no one meaning.

In addition, there is a joining together in the rhythm and movement as well as the pitched sounds taking place that produces a unique form of embodied communication that promotes shared experience of what Cross calls 'emotional body-states'(27). This propensity of music to promote social interaction and the bonding of people in group activity is why music is linked to the emergence of human culture (2001: 37-8; 2003: 27).

The music of non-Western, often indigenous cultures where group participation in music making is part of the fabric of social life provides convincing evidence of the therapeutic effects of making music together. Such evidence, from my field research among the Shona in Zimbabwe, is presented to support my argument that providing opportunities for group participation in music making should be central to music education. Throughout subSaharan Africa, group participation in music making is a common element of the ritual practice of indigenous religions as well as performance process in secular events that feature music. The prevalence of group participation can be viewed as part of a larger cultural aesthetic that encourages everyone to participate in music-making regardless of specialized ability (Turino 2000: 52-53). A familiar Shona proverb, 'if you can walk you can dance, if you can talk you can sing' aptly expresses the attitude behind the expectation that everyone participate. Implicit in this 'ethic of group participation' is the expectation that everyone contributes with their individual energy to the energy being generated by the group, to create a greater force than one can achieve alone. Equally common is the use of song and dance forms to heal and/or restore balance for entire communities as well as for disturbed 
individuals. John Blacking quotes the Venda about the efficacy of their national dance, Tshikona: "Tshikona makes sick people feel better, and old men throw away their sticks and dance. Tshikona brings peace to the countryside" (Blacking 1973:51; cf Friedson 1999).

An example from Shona culture lies in a didactic genre known as Ngano, Shona story-songs. Ngano is a secular art form which has historically served the purpose of teaching societal values such as honesty and respect to the children. These folk tales serve as evening entertainment and relaxation for children and anyone else from the village wishing to participate. The children are expected to learn the stories and songs that comprise the ngano and perform them for their elders at these evening story-telling events. They learn ngano by listening, memorizing, and participating. In this way ngano are passed on from one generation to the next. The sarungano (storyteller) is most often the grandmother. Ngano are told at the storyteller's house with all the village children as well as adults and visitors from other villages welcome. (Fortune1982: 10)

The sarungano's skill is developed from childhood throughout life and requires learning many stories and their accompanying songs. Ngano are the domain of the common people. There is not a specialized class of storytellers among the Shona, as in some other African societies. The sarungano has a good deal of freedom in how she or he builds the episodes of the stories. Although the basic content of the tales is consistent, it is unlikely that any two versions of a tale are exactly the same. (Fortune1974:ix-x)

Ngano combine two art forms: story-telling and song. The musical and narrative elements will not stand alone, a ngano is not complete without both the story and the song. Importantly, the song provides the vehicle for audience participation. It provides the connecting, transitional material between episodes, adds drama to the stories, heightens the emotional response from the audience, and always contains reference to the imagery and/or metaphorical elements in the stories (Mkanganwi in Fortune1980: i-ii). The song is introduced by the storyteller at the end of the first episode. The sarungano will sing a line and the audience will sing a line in response, back and forth, until the song is completed, in call and response form. The song provides a concise, but elliptical or allusive summary of the story, with its content being taken from the thematic material of the story. (Fortune1980: i)

The performance process of ngano is similar to that in many performance events, secular and sacred, that feature call and response singing. What is distinctive is the requirement that the children not only listen, but listen attentively enough to learn both the narrative and the song and be capable of getting up and performing it themselves. The inclusiveness of this practice, the way it bridges the generations from grandparents to young children, the way all the children are expected to perform promotes cohesiveness and mutual respect. Children earn the respect of their elders and peers by performing well and at the same time from a very early age they become accustomed to performing before a group. This builds self-confidence from an early age and breaks down the stage fright syndrome.

The cultural aesthetic embodied in ngano is the same as that found in dandanda and the many other forms of traditional dance among the Shona. It is the 'ethic of group participation' which carries with it the expectation that everyone contribute their individual energy to the group energy being generated. Ngano serve as an example of how music is valued among the Shona as a vehicle to communicate societal values to the children. This tradition illustrates the many levels in which music functions to promote well-being and societal cohesion. 
My research on dandanda song and dance among the Shona documents the 'ethic of group participation' - the combining of individual energy to create a larger force, like that of Tshikona, able to make sick people feel better and bring peace to the countryside. The Shona do not conceive of music as a thing outside themselves, but rather as a dynamic process, a force with communicative power. For those who sing and dance dandanda, the power or force generated through making music together - through group participation - achieves positive effects in multiple ways. It achieves contact with the ancestral spirits at all-night ceremonies where the spirits materialize through their mediums to counsel the people about their problems, be they community, familial, or personal. Berliner (1978: 191) says, "Active participation in the music is characteristic of the bira ..., and reflects the communal nature of the music, in which highly talented or professional musicians can express themselves without restraint within the same context as beginners." That the 'force' or energy created through group performance of dandanda has a positive effect on how the individual performer feels both physically and emotionally was revealed during my field research through participantobservation and by asking participants to describe their experience when they perform dandanda.

Certainly staying awake all night hardly seems, to a Westerner such as myself, like a therapeutic thing to do. But much to my surprise, at the close of the first bira I ever attended (August 1993), Pasencia Chidzere told me that the headache she had when she came to the ceremony the night before was now gone. Comments such as these led me to realize that group participation in performance of music has a therapeutic dimension that I needed to address (cf Thram 1999). Subsequent research in the Eastern Cape of South Africa with Xhosa healer-diviners (2000-2004) that documented ritual intlombe song-dance events for the ancestral spirits and healing services in the indigenized Zion Church that call on the Holy Spirit, served to reinforce my findings among the dandanda dancers regarding the therapeutic efficacy of group participation in music making (cf Thram 2006). For Xhosa healers, singing and dancing at intlombe and for Zion Church members dancing the circular dance of their purification ritual, the motivation for participation is the same: they participate for the sense of belonging afforded by being part of a group united for a common purpose and for the improvement in how they feel when they bond together to make music.

The foregoing substantiates the biological basis of our ability to experience a therapeutic effect from music making and suggests that this capacity exists in our ability, through our nervous system and our sense of hearing, to bond to the rhythmic flow when making music. Careful consideration of the process involved suggests that two phenomena occur when people make music together: first, the bonding of each participant's physical energy to the rhythmic flow of the music being created; and second, losing oneself in the act of musical expression and thereby achieving a loss of self-consciousness - a shedding of the ego as the individual becomes one with the group (Thram 1999: 301). I submit that the unique way that music making allows for "the simultaneous projecting and dissolving of the self in performance" (Slobin 1993: 41) is in and of itself therapeutic. The performer simply feels better throughout his or her entire being because of the letting go and bonding to group energy that takes place.

5 Dandanda is an indigenous form of ritual dance with its own song repertoire and distinctive drum (ngoma) and gourd rattle (bosho) style. It is performed by the Zezuru, the largest sub-group of the Shona, at all-night ceremonies for the ancestral spirits (biras) and at government sponsored events including the annual regional and national traditional dance competitions. 


\section{Conclusion}

In this presentation an attempt was made to locate the therapeutic efficacy of group participation in music making in both our biological capacity to make music and the presence of group music activities cross-culturally, specific to all the various cultures of the world. Evidence was presented of how and why 'music is natural' and basic to our biological capabilities and also how and why 'music is cultural' and gives rise to unique communicative possibilities that involve simultaneous embodied sharing of energy made possible through the 'group experience of the one' (Kapferer 1983) musical participation affords. That group musical activities promote social cohesion, foster positive group identity, and enhance one's sense of well-being was used as evidence for the need to maintain and promote them as part of every child's school experience.

I am not suggesting the competitive, competence-based model found throughout the Western world and, due to the Colonial imprint, throughout much of the non-Western world as well, must be abandoned. But, my concern is for the many students who do not participate in the music curriculum beyond primary school, and therefore have few opportunities for group participation in music making beyond being spectators at pop concerts and perhaps singing and dancing with their friends at parties. I am even more concerned for the many others who confine themselves to solitary listening via i-pods and partake in little actual group socializing such as that afforded by making music together.

The present-day popularity of drum workshops held for everyone from corporate employees to retirees to school children to patients in group therapy suggests a broader understanding of the power of group participation in music making to positively affect how people feel. The fact that group participation in making music by its very nature requires 'keeping together in time' (cf McNeill 1995) and serves as a potent form of communication makes it an easily accessible antidote to the isolation and sense of alienation that characterizes the experience of many in today's world. I suggest that music educators are ideally positioned to engage their students in group musical activities that can serve to ameliorate this increasingly prevalent reality of modern life.

\section{References}

Barz, Gregory. 2006. Singing for Life: HIV/AIDS and Music in Uganda. New York and London: Routledge.

Berliner, Paul. 1978. Soul of Mbira. Berkeley and Los Angeles: University of California Press.

Biesele, Meagan. 1993. Women Like Meat. Bloomington: Indiana University Press.

Blacking, John. 1973. How Musical Is Man? Seattle and London: University of Washington Press.

Byron, Reginald, ed. 1995. Music Culture and Experience Selected Papers of John Blacking. Chicago and London: University of Chicago Press.

Cross, Ian. 2001. "Music, Cognition, Culture, and Evolution." in The Biological Foundations of Music. R. J. Zatorre and I. Peretz, eds. New York, NY: The New York Academy of Sciences. 30-42. 
. 2003. "Music and Biocultural Evolution." in The Cultural Study of Music. M. Clayton, R. Herbert, and R. Middleton, eds. London and New York: Routledge.

Erlmann, Veit. 2004. "But What of the Ethnographic Ear? Anthropology, Sound, and the Senses." in Hearing Cultures Essays on Sound, Listening and Modernity. V. Erlmann, Ed. Oxford, New York: Berg.

Feld, Steven and Charles Keil. 1994. Music Grooves. Chicago: University of Chicago Press.

Ficino, Marsilio. 1989. Three Books on Life. ed. and trans. Carol Kaske and John R. Clark. Binghamton: Medieval and Renaissance Texts and Studies.

Fortune, George. 1980. ed. Ngano. Salisbury, Zimbabwe: Mercury Press. Vol. 1. (originally published by University of Rhodesia, 1973).

- 1982. ed. Ngano. Salisbury, Zimbabwe: Mercury Press. Vol. 2. (originally published by University of Rhodesia, 1974).

Friedson, Steven. 1996. Dancing Prophets. Chicago: University of Chicago Press.

Gouk, Penelope. 2000a. "Introduction." in Musical Healing in Cultural Contexts. P. Gouk, Ed. Brookfield, VT: Ashgate Publishing Co. 1-25.

. 2000b "Sister disciplines? Music and Medicine in historical perspective." in Musical Healing in Cultural Contexts. Brookfield, VT and Hants, England: Ashgate Publishing Co. 171-216.

. 2000c. "Music, Melancholy, and Medical Spirits in Early Modern Thought." In Music as Medicine. P. Horden, Ed. Burlington, VT and Hants, England: Ashgate Publishing Co. 173-194.

. 2004. "Raising Spirits and Restoring Souls: Early Modern Medical Explanations for Music's Effects." in Hearing Cultures Essays on Sound, Listening and Modernity.V. Erlmann, Ed. Oxford and New York: Berg. 87-105.

Horden, Peregrine. 2000. "Commentary on Part III, with a Note on Paracelsus." in Music as Medicine. P. Horden, Ed. Burlington, VT and Hants, England: Ashgate Publishing Co. 147-153.

Huron, David. 2001. "Is Music an Evolutionary Adaptation?" in The Biological Foundations of Music. R. J. Zatorre and I. Peretz, eds. New York, NY: The New York Academy of Sciences. 43-61.

Janzen, John. 1992. Ngoma. Berkeley: University of California Press.

Kapferer, Bruce. 1986. "Performance and the Structuring of Meaning and Experience." in The Anthropology of Experience. Urbana and Chicago: University of Illinois Press. 188203.

Koen, Benjamin, ed. 2008. The Oxford Handbook of Medical Ethnomusicology. London: Oxford University Press.

Laderman, Carol and Marina Roseman, eds. 1996. The Performance of Healing. New York and London: Routledge.

Levitin, Daniel J. 2006. This Is Your Brain on Music. New York, NY: Penguin Group. 
McNeill, William H. 1995. Keeping Together in Time. Cambridge: Harvard University Press.

Merriam, Alan. 1964. The Anthropology of Music. Evanston: Northwestern University Press.

Roseman, Marina. 1991. Healing Sounds of the Malaysian Rain Forest. Berkeley, Los Angeles, and Oxford: University of California Press.

Schellenberg, E. Glenn. 2001. "Music and Nonmusical Abilities." in The Biological Foundations of Music. R. J. Zatorre and I. Peretz, Eds. New York, NY: The New York Academy of Sciences. 355-371.

Schiesari, Juliana. 1992. The Gendering of Melancholia: Feminism, Psychoanalysis, and the Symbolics of Loss in Renaissance Literature. Ithaca, NY: Cornell University Press.

Schipperges, Heinrich. 1997. Hildegard of Bingen Healing and the Nature of the Cosmos. Princeton, NJ: Markus Wiener Publishers.

Slobin, Mark. 19931 Subcultural Sounds: Micromusics of the West. Hanover, NH: University Press of New England.

Storr, Anthony. 1992. Music and the Mind. London: HarperCollins Publishers.

Thram, Diane J. 1999. "Performance as Ritual - Performance as Art: Therapeutic Efficacy of Dandanda Song and Dance in Zimbabwe. PhD Dissertation. Indiana University.

2002. "Therapeutic Efficacy of Music-Making: Neglected Aspect of Human Experience Integral to Performance Process." Yearbook of Traditional Music Vol. 34. 129-138.

. 2006. "Music and Healing: Sites of Power in the Rituals of Xhosa Healers/Diviners and the Zion Church in South Africa." Musike' 1. 59-70.

Turino, Thomas. 1993. Moving Away from Silence. Chicago and London: University of Chicago Press.

. 2000. Nationalists, Cosmopolitans, and Popular Music in Zimbabwe. Chicago and London: University of Chicago Press.

2008. Music as Social Life: The Politics of Participation. Chicago and London: University of Chicago Press.

Turner, Victor. 1968. The Drums of Affliction. London: Hutchinson \& Co. 1977. The Ritual Process. Ithaca, NY: Cornell University Press.

Voss, Angela. 2001. "Marsilio Ficino, the Second Orpheus." in Music as Medicine. P. Horden, Ed. Burlington, VT: Ashgate Publishing Co. 154-172.

Walker, D. P. 1958. Spiritual and Demonic Magic from Ficino to Campanella. London: Warburg Institute.

1972. The Ancient Theology: Studies in Christian Platonism from the Fifteenth to the Eighteenth Century. London: Duckworth. 